Ann. Biol. anim. Bioch. Biophys., 1977, 17 (5 A), 749-758

\title{
Immunocytochemical localization of acrosin in the anterior segment of the acrosomes of ram, boar and bull spermatozoa
}

\author{
par J.-E. FLÉCHON, D. HUNEAU, C. R. BROWN *, R. A. P. HARRISON * \\ Station centrale de Physiologie animale, \\ I.N.R.A., 78350 Jouy-en-josas, France \\ * A.R.C. Institute of Animal Physiology, Animal Research Station, \\ 307 Huntingdon Road, Cambridge CB3 OJQ, U.K.
}

\begin{abstract}
Summary. Highly purified ram acrosin was used to raise antisera in virgin rabbif does. The antisera, of proven specificity, were then used in combination with fluorescein or peroxidase - labelled anti-rabbit antisera to locate acrosin in spermatozoa of ram, bull and boar. Due to the immunological similarity of the different acrosins, staining of the acrosomal region was obtained in smears of spermatozoa from all three species. Only the anterior segment was stained in these spermatozod; there was no reaction in the equatorial segment, or in the postacrosomal region. The specificity of the stain was clearly demonstrated. Such a distribution of acrosin parallels the distribution of hyaluronidase shown in previous studies (Fléchon and Dubois, 1975). However, little or no staining could be obtained on spermatozoa that had previously been disrupted. A possible explanation is proposed.
\end{abstract}

\section{Introduction.}

Acrosin, a trypsin-like proteinase found in spermatozoa, is believed to play an essential role in fertilization by aiding the spermatozoon to penetrate the zona pellucida surrounding the egg (Mc Rorie and Williams, 1974). The precise cellular location of this enzyme is of considerable interest since such knowledge would aid in elucidating its mode of action.

Biochemical studies have indicated that acrosin is largely bound to the sperm head, probably to the inner acrosomal membrane (Stambaugh and Buckley, 1969 ; Brown and Hartree, 1974 ; Schill and Wolff, 1974 ; Zahler and Doak, 1975), and observations of lysis of gelatin films by spermatozoa (believed to be due to acrosin activity) have certainly indicated that proteolytic activity is confined to the acrosomal region (Wendt ef al., 1975 ; Landa, 1975). Localization of acrosin has recently been achieved by immunocytochemistry using antisera against acrosin (Garner ef al., 1975 ; Morton, 1975 ; Schill et al., 1975) ; the results of these studies have been in accord with those of the previous workers. However, the precise location of acrosin 
within the acrosome is still in doubt : some authors imply that all the acrosomal region contains acrosin, although their published photographs show otherwise. Moreover, the visual localization methods used so far have only indicated the two-dimensional distribution of the enzyme, they do not show whether the enzyme is bound (or free) within the acrosome and to which part. Using a combination of biochemical and immunocytochemical techniques, we are therefore carrying out further studies to define the intracellular location of acrosin ; this paper presents our preliminary findings.

\section{Materials and Methods.}

\section{Acrosin purification.}

Acrosin (EC 3.4.21.10) (mol. wt. 37000,3 p. 100 carbohydrate) was isolated from ejaculated ram spermatozoa and purified as described by Hartree (1977). The preparation obtained was stable and electrophoretically pure, with a specific activity of at least 100 international units/mg (using $N$ - $\alpha$-benzoyl-L-arginine ethyl ester as substrate); it contained no trace of contaminating hyaluronidase activity.

\section{Preparation and characterization of antisera.}

Antisera against acrosin were raised in virgin rabbit does using the multiple intradermal injection technique of Vaitukaitis et al. (1971). The antigen injection consisted of $500 \mu \mathrm{g}$ acrosin and $5 \mathrm{mg}$ freeze-dried tubercle bacilli (BCG, Institut Pasteur) in $1 \mathrm{ml}$ saline emulsified with $1 \mathrm{ml}$ complete Freund's adjuvant ; concomitantly, a suspension of $2.5 \times 10^{9}$ cells of Hemophilus pertussis (Institut Pasteur) was also injected intradermally. Serum was obtained 3 and 6 weeks later.

Characlerization of antibody activity in sera was carried out by immunodiffusion in agar gel (Agar Noble, Difco). The holes $(6 \mathrm{~mm}$ diameter, $12 \mathrm{~mm}$ apart centre to centre) were filled with various dilutions of sera or acrosin in buffered saline $\mathrm{pH} 7.3$ (Kabat and Mayer, 1961). Crude acrosin (fraction S3/4 of procedure of Brown ef al., 1975) and bovine trypsin (Sigma) were compared with acrosin. Diffusion was allowed to proceed for $24 \mathrm{hrs}$ at room temperature, and plates were observed either unstained or stained for acrosin activity (Garner ef al., 1975) using $N$ - $\alpha$-benzoyl-DLarginine- $\beta$-naphthylamide $\mathrm{HCl}$ (Sigma) as substrate and Fast Blue BB (Sigma) as coupling dye.

\section{Preparation of sperm samples.}

Ejaculated spermatozoa from fertile rams, boars and bulls were used in the experiments. The spermatozoa were either used directly ds diluted semen or they were washed 3 times in phosphate buffered saline or by means of a Ficoll-containing medium according to Harrison (1976). A portion of each washed sample was fixed for $10 \mathrm{~min}$ in $0.175 \mathrm{M}$-cacodylate buffer $\mathrm{pH} 7.3$ containing $1 \mathrm{p} .100$ formaldehyde, and then washed in buffered saline $\mathrm{pH}$ 7.3. Another portion was frozen and thawed twice; the rest was used intact. 


\section{Immunocyfochemistry.}

Basically acrosin detection was carried out by an indirect method (Coons, 1958) using fluorescein- or peroxidase-labelled sheep anti-rabbit globulins (Instifut Pasteur) to label rabbit anti-acrosin globulins that had reacted with spermatozoa. Peroxidase activity was defected by reaction with the substrate 3, 3'-diaminobenzidine tetrahydrochloride (Sigma) (Graham and Karnovsky, 1966).

Two approaches were adopted. In the first, the reaction of the spermatozoa with antl-acrosin was carried out with the cells smeared on a slide : an air-dried smear was prepared, rinsed in buffered saline and covered with a 1/40-1/60 dilution of antl-acrosin antiserum in buffered saline; after $30 \mathrm{~min}$ incubation at room temperature, the smear was washed and further treated with labelled anti-globulin antiserum in the same way; finally the smear was washed and mounted in glycerol. In the second approach, the reaction with anti-acrosin was carried out with the cells in suspension : washed intact or disrupted spermatozoa (about $10^{8}$ cells $/ \mathrm{ml}$ ) were incubated in a 1/2-1/20 dilution of anti-acrosin antiserum in buffered saline for 15$30 \mathrm{~min}$ at room temperature; the spermatozoa were then washed and smeared and treated with labelled anti-globulin antiserum as in the first approach. Only ram spermatozoa were used in the second approach, and, for treatment of living cells, sera were heated at $56^{\circ} \mathrm{C}$ for $30 \mathrm{~min}$ to destroy complement.

Since even normal sera may react non-specifically with spermatozoa (Beck, Edwards and Young, 1962), the following control experiments were carried out on smeared samples, to ascertain the specificity of any reaction observed. Anti-acrosin anti-serum was omitted, or replaced by preimmune serum, or replaced by antiserum absorbed with acrosin $\left(1 \mathrm{mg} / \mathrm{ml} ; 1 \mathrm{hr}\right.$ at $37^{\circ} \mathrm{C}$ followed by overnight at $4{ }^{\circ} \mathrm{C}$, then centrifuged). Furthermore, attempts were made to reduce background staining by pretreating smeared samples with normal sheep serum or with human serum albumin (Centre de Transfusion Sanguine, Lille) in buffered saline, or by heating antisera at $56^{\circ} \mathrm{C}$ for $30 \mathrm{~min}$ or by absorbing antisera with homologous spermatozoa fixed in 1 p. 100 glutaraldehyde for $1 \mathrm{hr}$ (this latter treatment destroys the acrosin's antigenicity in such cells). Some of these controls were also carried out on spermatozoa treated in suspension.

\section{Results.}

The specificity of the anti-acrosin antisera was established (figs. 1,2). Preimmune sera gave no precipitation line with either crude or purified acrosin ; antisera gave a single precipitation line (containing acrosin activity) with both of these, but no lines with bovine trypsin. The purified acrosin did not react with anti-hyaluronidase antiserum used in an earlier study (Fléchon, 1975), although crude acrosin did, and ovine hyaluronidase did not react with anti-acrosin antisera.

When intact spermatozoa from bull, boar and ram were smeared onto slides and tested for acrosin immunocytochemically, the anterior part of the head of most of the spermatozoa became stained. This stained area was sharply delineated at its posterior end in a curve, convex towards the anterior end, and it extended less than 
two-thirds of the head length in ram and bull spermatozoa (figs. 3, 5, 7, 10, 12) and about three-quarters in boar spermatozoa (figs. 13,15); there was no stain in the postacrosomal region. The semi-lunar unstained area behind the stained region appeared to be about one-fifth of the stained area in ram and bull, and about one-third of the stained area in boar. By relating these observations to others made on the species-specific shapes and sizes of acrosomal regions (Bustos-Obregon and Fléchon, 1975) we were able to deduce that the stain was confined to the anterior segment of the acrosome : the equatorial segment remained unstained (fig. 6).

No major differences were observed between washed and unwashed spermatozoa, between spermatozoa washed by different methods, or between fixed and unfixed spermatozoa, although better morphological preservation was obtained with fixation. Staining was generally uniform (figs. 7, 10,12,15), but when it was weak, as after high dilution of antisera, it sometimes appeared only on the anterior rim of the head (fig. 13) and/or (in ram particularly) at the posterior limit of the stained area (fig. 9). Staining was unaltered when antiserum was used that had been heat-treated or absorbed with fixed spermatozoa (figs. 9, 12). Staining was also unaltered in smears that had been pretreated with normal sheep serum or with human serum albumin, but in these smears the background was generally reduced (figs. 7 , $12,13,15)$.

Staining was not obtained when preimmune rabbit serum was used (figs. 4, 11) or when labelled anti-rabbit antiserum was used alone. Staining was abolished when anti-

\section{PLATE I}

FIG. 1. - Immunodiffusion of purified acrosin against preimmune and immune sera from two rabbits. Centre well : purified acrosin $(300 \mu \mathrm{g} / \mathrm{ml})$. Peripheral wells : (a), preimmune serum from female 2053 ; (b), antiserum from female 2053 ; (c), as (b) but diluted $1 / 2$; (d), antiserum from female 2052, diluted $1 / 2 ;(e)$, antiserum from female 2052; (f), preimmune serum from female 2052. Note one continuous precipitation line, absent in front of $(a)$ and (f) and broader in front of (b) and $(e)$.

FIG. 2. - As figure 1, except that centre well contained crude acrosin $(300 \mu \mathrm{g} / \mathrm{ml})$.

FIG. 3. - Ram spermatozoa, washed in Ficoll-sucrose medium. Treated with anti-acrosin antiserum and peroxidase-labelled anti-rabbit antiserum in buffered saline containing 2 p. 1000 human serum albumin. $\times 3200$. Note only anterior segment of acrosome stained.

FIG. 4. - As figure 3, but anti-acrosin antiserum replaced by preimmune serum. $\times 3200$. Note absence of staining.

FIG. 5. - Bull spermatozoa (unwashed), dilufed in saline and fixed in formaldehyde. Treated with antiacrosin serum and peroxidase-labelled anti-rabbit antiserum in buffered saline. $X 3200$. Note only anterior segment of acrosome stained, as in ram : biconvex lens-shaped equatorial segment and long postacrosomal region remain unstained.

FIG. 6. - Diagram showing relative proportions of different regions of the sperm head in the three species : (a), ram ; (b), boar ; (c), bull. Stippled area corresponds to stained anterior segment of acrosome ; ES, equatorial segment of acrosome ; PAR, postacrosomal region. 
acrosin serum was pretreated by absorption with purified acrosin (figs. 8, 14). In no cases was staining of other parts of the sperm cell observed, except occasionally a low background on some tails.

However, as soon as the spermatozoa had been disrupted, as after freezing and thawing, the number of spermatozoa in a smear that could be stained for acrosin immunocytochemically was greatly reduced. The proportion of stained spermatozoa in a sample appeared to be correlated approximately with the proportion of spermatozoa whose acrosomes were intact : those samples in which disruption was efficient (as seen by electron microscopy) contained few spermatozoa stainable for acrosin, while those samples in which disruption was less efficient contained more stainable spermatozoa. Biochemical assays of acrosin activity in these disrupted samples showed that high levels of activity were always present in the head fractions, as has been observed previously (Brown, Andani and Hartree, 1975).

\section{PLATE \|}

FIG. 7. - Ram spermatozoa, washed in phosphate-buffered soline, fixed in formaldehyde. Pretreated with non-immune sheep serum, then treated with anti-acrosin antiserum and fluorescein-labelled anti-rabbit antiserum in buffered saline containing 2.5 p. 1000 human serum albumin. $X 600$. Note anterior segments still stained.

FIG. 8. - As figure 7, but anti-acrosin antiserum absorbed with purified acrosin before use. $X 600$. Note absence of staining.

FIG. 9. - Ram spermatozoa (unwashed), diluted in saline and fixed in formaldehyde. Before use, both antisera absorbed against glutaraldehyde-fixed spermatozoa from same animal. $X 1500$. Note dilution of antisera reduced staining except on posterior part of anterior segment.

FIG. 10. - Bull spermatozoa, washed in phosphate-buffered.saline and fixed in formaldehyde. Treated with anti-acrosin antiserum and fluorescein-labelled anti-rabbit antiserum in buffered saline containing 2.5 p. 1000 human serum albumin. $\times 600$. Note only anterior segments stained.

FIG. 11. - As figure 10, but anti-acrosin antiserum replaced by preimmune serum. $X 600$. Note absence of staining.

FIG. 12. - As figure 10, except that smear pretreated with 2.5 p. 1000 human serum albumin and antiacrosin antiserum absorbed before use with glutaraldehyde-fixed spermatozoa from same animal. $\times 600$. Note reduced background.

FIG. 13. - Boar spermatozoa, washed in phosphate-buffered saline and fixed in formaldehyde. Pretreated with 2.5 p. 1000 human serum albumin, treated with anti-acrosin antiserum and fluoresceinlabelled anti-rablit antiserum in buffered saline containing 2.5 p. 1000 human serum albumin. $\times 600$. Note only anterior segments stained, sometimes more heavily on the marginal thickening.

FIG. 14. - As figure 13, but anti-acrosin antiserum absorbed with purified acrosin before use. $\times 600$. Note absence of staining.

FIG. 15. - As figure 13, but antiserum less diluted. $X 1500$. Note staining of anterior segment ; long ogive-shaped equatorial segment (arrow) and short postacrosomal region remain unstained. 
Attempts to stain for acrosin in spermatozoa by carrying out the initial antigenantibody reaction with the cells in suspension were completely unsuccessful. Neither intact nor disrupled cells could be stained significantly, despite the fact that considerable acrosin activity was detectable in them.

\section{Discussion.}

In work of this nature, the specificity of the antiserum is crucial to the validity of the results obtained. Our antigen was pure and stable, and the specificity of the antisera raised against it was clearly demonstrated. Garner et al. (1975) blocked the active site of their antigen acrosin with $N$ - $\alpha$-tosyl-L-lysine chloromethyl ketone to prevent degradation; we found this precaution to be unnecessary. A second point of interest was the ability of the antiserum raised against ram acrosin to cross-react with acrosins of bull and boar ; such cross-reactivity has been noted previously by Garner ef al. (1975) and Schill ef al. (1975). Like Garner ef al. (1975), we could not detect any cross-reactivity between anti-acrosin and bovine trypsin, although a reverse cross-reactivity between anti-trypsin and acrosin has been reported (Stambaugh and Smith, 1974).

The location of acrosin in the anterior segment only of the acrosome thus appears clearly established, and confirms the impression given by the illustrations published by Morton (1975) and by Schill ef al. (1975); acrosin cannot be detected in the equatorial segment of the acrosome or in the postacrosomal region. Hyaluronidase is similarly distributed within the acrosome (Fléchon and Dubois, 1975 ; Fléchon, 1975), and one is tempted to point out that this localized distribution fits well with the postulated function of these enzymes in egg penetration. The acrosome reaction, which unmasks acrosomal enzymes just prior to egg penetration, for action on external substrates, takes place over the anterior segment of the acrosome only; the equatorial segment may be seen virtually unaltered in spermatozoa found within the zona pellucida (Bedford, 1968 ; Szöllösi and Hunter, 1973 ; Fléchon, personal observations). From this, it might be expected that any enzymes involved in zona penetration (as is acrosin) would have to be mainly if not entirely located in the anterior segment.

However, a major new problem must now be solved : why does it become hard to detect acrosin immunocytochemically in spermatozoa treated for acrosome disruption? The failure casts doubt upon the above interpretation of our findings. If, as seems likely from biochemical studies (Brown and Hartree, 1974 ; Schill and Wolf, 1974), acrosin is bound to the inner acrosomal membrane, one would expect antiacrosin globulin to be unable to react with acrosin in intact spermatozoa because of the barriers of the plasma and outer acrosomal membranes, through which globulin is presumably unable to penetrate. Thus it is not surprising that infact cells treated with antiserum in suspension do not stain. During the process of preparing airdried smears, it is to be expected that membranes will be disrupted and will allow penetration of antibody; hence staining of cells in smears will occur, even if previously these have been intact. But disruption of the spermatozoa by freezing and thawing should increase the accessibility of the acrosin and it would be logical to expect increased immuno-cytochemical staining in smears of these disrupted spermatozoa. 
That the opposite is in fact true raises several questions. Biochemical tests showed that acrosin was present on the sperm heads in our disrupted preparations just prior to immunocytochemical treatment. It is possible that disruption rendered the acrosin more soluble in the media used for immunocytochemistry, but this explanation seems insufficient. A more interesting possibility is provided by our recent finding (Brown, Harrison, and Mercer, in preparation) that there is no active acrosin in intact spermatozoa : it is all in the zymogen form, proacrosin. The acrosin is rapidly activated following cell disruption. It may be that although anti-acrosin can react with exiracted (soluble) active acrosin, it is unable to react with bound active acrosin ; such postulated behaviour would find a parallel in the behaviour of several of the acrosin inhibitors found in semen (Brown and Hartree, 1976 ; also Brown and Harrison, unpublished observations). However, perhaps the antibody can react with bound proacrosin. From the results of Brown, Harrison and Mercer (in preparation), little or no proacrosin would be present in disrupted cells, only bound acrosin. We suggest that the antibody cannot react with this bound acrosin, and that any staining observed in spermatozod is due to reaction of the anti-acrosin with proacrosin. Much experimentation will be needed to prove or disprove this possibility. In the meantime, due to the apparent inconsistencies in our findings, the precise location of active acrosin in spermatozoa remains unclear.

Reçu en février 1977.

Accepté en ovril 1977.

Acknowledgments. - We are grateful to R. Scandolo for printing the plates and to Mrs A. Daifuku for editorial assistance.

Résumé. Des lapines vierges ont été utilisées pour l'obtention d'antisérums après microinjections d'acrosine purifiée à partir de spermatozoïdes éjaculés de bélier. La spécificité des anticorps a été testée par immunodiffusion : il se forme une ligne de précipitation entre l'antigène et les antisérums et une activité acrosine y est décelable.

Les frottis de spermatozoīdes de bélier, verrat et taureau ont été traités par une technique immunocytochimique indirecte, à l'aide d'antisérums anti-lapin marqués à la fluorescéine ou à la peroxydase. De nombreux traitements témoins ont montré la spécificité de la méthode et de la coloration obtenue. Des résultats analogues ont été observés sur les spermatozoïdes des trois espèces éfudiées, ce qui indique un croisement entre les anticorps anti-acrosine de bélier ef l'acrosine de taureau et de verrat.

Dans les trois espèces, l'acrosine est uniquement localisée dans le segment antérieur de l'acrosome des spermatozoïdes éjaculés. Elle est absente du segment équatorial. Cette ségrégation est similaire à celle de la hyaluronidase. Les enzymes intervenant lors de la pénétration de la zone pellucide de l'œuf semblent donc essentiellement présents dans le segment ontérieur de l'acrosome.

Cependant, une coloration immunocytochimique des spermatozoïdes dont l'acrosome est désintégré est difficile à obtenir alors que l'activé enzymatique reste liée aux cellules. Une explication est proposée. 


\section{References}

BECK S. J., EDWARDS R. G., YOUNG M. R., 1962. Immune fluorescence technique and the isoantigenecity of mammalian spermatozoa. J. Reprod. Fert., 4, 103-110.

BEDFORD J. M., 1968. Ultrastructural changes in the sperm head during fertilization in the rabbit. Am. J. Anat., 123, 329-358.

BROWN C. R., ANDANI Z., HARTREE E. F., 1975. Studies on ram acrosin. Isolation from spermatozoa, activation by cations and organic solvents, and influence of cations on its reaction with inhibitors. Biochem. J., 149, 133-146.

BROWN C. R., HARTREE E. F., 1974. Distribution of a trypsin-like proteinase in the ram spermatozoon. J. Reprod. Fert., 36, 195-198.

BROWN C. R., HARTREE E. F., 1976. Effects of acrosin inhibitors on the soluble and membranebound forms of ram acrosin and a reappraisal of the role of the enzyme in fertilization. Hoppe-Seyler's Z. Physiol. Chem., 357, 57-65.

BUSTOS-OBREGON E., FLÉCHON J.-E., 1975. Comparative scanning electron microscope study of boar, bull, and ram spermatozoa. Cell Tissue Res., 161, 329-342.

COONS A. H., 1958. Fluorescent antibody methods, 399. In DANIELLI J. F., General cytochemical methods, Vol. 1, Acad. Press, N. Y.

FLÉCHON J.-E., 1975. Immunocytochemical localization of hyaluronidase in the sperm acrosome of farm mammals. 3rd internat. Symp. Immunol. Reprod. (Varna).

FLÉCHON J.-E., DUBOIS M. P., 1975. Localisation immunocytochimique de la hyaluronidase dans les spermatozoïdes de Mammifères domestiques. C. R. Acad. Sci. Paris, sér. D, 280, 877-880.

GARNER D. L., EASTON M. P., MUNSON M. E., DOANE M. A., 1975. Immunoffuorescent localization of bovine acrosin. J. exp. Zool. 191, 127-131.

GRAHAM R. C., Jr, KARNOVSKY M. J., 1966. The early stages of absorption of injected horseradish peroxidase in the proximal tubules of mouse kidney : ultrastructural cytochemistry by a new technique. J. Histochem. Cytochem., 14, 291-302.

HARRISON R. A. P., 1976. A highly efficient method for washing mammalian spermatozoa. J. Reprod. Fert., 48, 347-353.

HARTREE E. F., 1977. Spermatozoa, eggs and proteinases. Biochem. Soc. Trans., 5, 375-394.

KABAT E. A., MAYER M. M., 1961. Experimental immunochemistry. 2nd ed., Thomas, Springfield.

LANDA V., 1975. Activity and subcellular localization of proteolytic enzymes of boar and rabbit spermatozoa. Folia Biol. (Praha), 21, 192-195.

Mc RORIE R. A., WILLIAMS W. L., 1974. Biochemistry of Mammalian Fertilization. Ann. Rev. Biochem., 43, 777-803.

MORTON D. B., 1975. Acrosomal enzymes : immunochemical localization of acrosin and hyaluronidase in ram spermatozoa. J. Reprod. Fert., 45, 375-378.

SCHILL. W. B., SCHLEUNING W. D., FRITZ H., WENDT V., HEIMBURGER N., 1975. Immunofluorescent localization of acrosin in spermatozoa by boar acrosin antibodies. Natruwissenschaften, 62, 540-541.

SCHILL W. B., WOLFF H. H., 1974. Ultrastructure of human sperm acrosome and determination of acrosin activity under conditions of semen preservation. Int. J. Ferfil., 19, 217-223.

STAMBAUGH R., BUCKLEY J., 1969. Identification and subcellular localization of the enzymes effecting penetration of the zona pellucida by rabbit spermatozoa. J. Reprod. Fert., 19, 423-432.

STAMBAUGH R., SMITH M., 1974. Amino acid content of rabbit acrosomal proteinase and its similarity to human trypsin. Science, N. Y., 186, 745-746.

SZÖLLÖSI D., HUNTER R. H. F., 1973. Ulitrastructural aspects of fertilization in the domestic pig: sperm penetration and pronucleus formation. J. Anat., 116, 181-206.

VAITUKAITIS J., ROBBINS J. B., NIESCHLAG E., ROSS G. T., 1971. A method for producing specific antisera with small doses of immunogen. J. clin. Endocr. Mefab., 33, 988-991.

WENDT V., LEIDL W., FRITZ H., 1975. The lysis effect of bull spermatozoa on gelatin substrate film. Methodical investigations. Hoppe-Seyler's Z. Physiol. Chem., 356, 315-324.

ZAHLER W. L., DOAK G. A., 1975. Isolation of the outer acrosomal membrane from bull sperm. Biochim. biophys. Acta, 406, 479-488. 